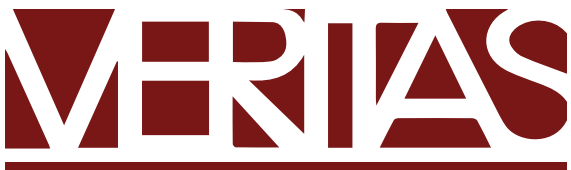

$\begin{array}{lllllllllll}P & O & R & T & O & A & L & E & G & R & E\end{array}$

\title{
A RECONSTRUÇÃO HABERMASIANA DO PROJETO KANTIANO DE CONSTITUCIONALIZAÇÃO DO DIREITO INTERNACIONAL'
}

\author{
The habermasian reconstruction of the kantian project of \\ constitutionalization of international law \\ Reconstrucción habermasiana del proyecto kantiano de \\ constitucionalización del derecho internacional
}

Jorge Adriano Lubenow ${ }^{2}$ Universidade Federal da Paraíba, João Pessoa, PB, Brasil.

\footnotetext{
1 Este artigo resulta de uma pesquisa de pós-doutorado financiada pela CAPES sobre democracia transnacional em Jürgen Habermas realizada junto à Europa-Universität Flensburg, Alemanha, no semestre de inverno 2014-2015, sob a orientação do Prof. Dr. Hauke Brunkhorst. Uma versão preliminar foi apresentada na disciplina "Transnational democracy Europe and beyond" no semestre 2015/1 e coordenada pelo professor Brunkhorst; na disciplina "Filosofia Política" no mestrado em Filosofia da UFPB em 2017/1; e em uma aula especial no mestrado e doutorado em Direito do Centro de Ciências Jurídicas da UFPB em outubro de 2018.

2 Doutor em Filosofia pela UNICAMP (2007) e Pós-doutor em Filosofia pela Europa-Universität Flensburg, Alemanha (2015) e pelo CNPq/FAPEPI (2010). Professor Associado I do DFE e Professor permanente do Programa de Pós-graduação em Filosofia da Universidade Federal da Paraíba (UFPB), Campus I - João Pessoa, PB, Brasil, na linha Ética e Filosofia Política. É coordenador do Centro de Pesquisas em Democracia da UFPB (www.ufpb.br/cepede) e do Grupo de Pesquisa em Democracia (CNPq/UFPB). http://orcid.org/0000-0001-6043-4538. E-mail: jlubenow@hotmail.com
} 


\section{Resumo}

Este artigo trata da crítica habermasiana ao projeto kantiano de constitucionalização do direito internacional, reconstruído da perspectiva procedimental do direito e da democracia deliberativa. Embora Kant tenha dado um passo importante modificando a compreensão do direito internacional de um direito de Estados para um direito cosmopolita, e esse se institucionalizado em organizações e instituições internacionais, a simples extensão da constitucionalização do direito para o âmbito das relações interestatais não seria mais suficiente para reequacionar a atual relação assimétrica entre poder e direito na esfera internacional que resulta da política de poder unilateral e militar norte-americana e que em nome de uma moralização etnocentrista substitui o direito pelo ethos. Para Habermas, a constitucionalização do direito internacional apenas teria alguma chance nas circunstâncias históricas atuais através da reformulação dos conceitos kantianos de república mundial, soberania nacional, direito estatal, nação e cidadão, bem como das modificações na estrutura da sociedade mundial, por exemplo, a reforma das Nações Unidas. Em contrapartida, a proposta habermasiana de democracia constitucional transnacional teria a vantagem de definir melhor o curso da constitucionalização do direito internacional e ser uma ordem constitucional global mais justa e democrática.

Palavras-chave: Jürgen Habermas. Immanuel Kant. Constitucionalização do direito internacional. Democracia transnacional.

\section{Abstract}

This paper is about the Habermasian critique to the Kantian project of constitutionalization of international law, reconstructed from the procedural perspective of law and deliberative democracy. Although Kant has taken an important step by modifying the understanding of international law from a right of states to a cosmopolitan right, and this has been institutionalized in international organizations and institutions, the simple extension of the constitutionalization of law to the scope of inter-state relations would no longer be enough to re-equate the current asymmetrical relationship between power and law in the international sphere which results from the US unilateral and military power politics and which in the name of an ethnocentric moralization replaces the law by ethos. For Habermas, the constitutionalization of international law would only have any chance in the current historical circumstances by reformulating Kantian concepts of world republic, national sovereignty, state law, nation, and citizen, as well as by changing in the world society structure, for example, the reform of the United Nations. In contrast, the Habermasian proposal of a transnational constitutional democracy would have the advantages of better defining the 
course of the constitutionalization of international law and of being a more just and democratic global constitutional order.

Keywords: Jürgen Habermas. Immanuel Kant. Constitutionalization of International law. Transnational democracy.

\section{Resumen}

Este artículo trata sobre la crítica de Habermas al proyecto kantiano de constitucionalización del derecho internacional, reconstruido desde la perspectiva procedimental del derecho y de la democracia deliberativa. Aunque Kant ha dado un paso importante, cambiando la comprensión del derecho internacional, un derecho de los Estados a un derecho cosmopolita e institucionalizado en las organizaciones y instituciones internacionales, la simple ampliación de la constitucionalización del derecho de las relaciones entre Estados ya no serían suficientes para restablecer la actual relación asimétrica entre el poder y derecho en el ámbito internacional, que resulta de la política del poder unilateral y militares note americana y que en nombre de una moralización etnocéntrica sustituye el derecho por el ethos. Para Habermas, la constitucionalización del derecho internacional sólo tendría alguna posibilidad en las actuales circunstancias históricas a través de la modificación de los conceptos kantianos de República mundial, soberanía nacional, derecho estatal, nación y ciudadano, así como los cambios en la estructura de la sociedad mundial, por ejemplo, la reforma de las Naciones Unidas. Por otro lado, la propuesta habermasiana de democracia constitucional transnacional tendría el ventaje de definir mejor el curso de la constitucionalización del derecho internacional y ser un orden constitucional global más justa y democrática.

Palabras clave: Jürgen Habermas. Immanuel Kant. Constitucionalización del derecho internacional. Democracia transnacional.

\section{Introdução}

Em outro artigo apresentei a crítica de Habermas à concepção etnocentrista norte-americana de moralização do direito internacional, que coloca o ethos no lugar do direito através de uma política externa unilateral e militar 
que ignora o direito internacional, rejeita as Nações Unidas e despreza os pontos de vista normativos da democracia e dos direitos humanos. ${ }^{3}$

Na obra Der gespaltene Westen (HABERMAS, 2004), parte IV, Habermas trata do problema do "Ocidente dividido", cujo pano de fundo da discussão é a disputa entre duas interpretações diferentes do direito internacional, entre dois projetos de uma ordem constitucional cosmopolita: o projeto kantiano de regulamentação das relações jurídicas e o projeto hobbesiano de moralização da ordem política mundial pelo uso do poder imperial. Trata-se de "dois caminhos" pelos quais uma ordem cosmopolita poderia ser realizada: se pelos procedimentos juridicamente estabelecidos por uma organização mundial includente ou se pela força de um agente hegemônico.

Com o esboço de um "Estado cosmopolita", Kant já havia aberto o caminho e dado um passo decisivo para além do direito internacional restrito somente aos Estados. Depois de duas guerras, a constitucionalização do direito internacional avançou no caminho apontado por Kant em direção ao direito cosmopolita e se institucionalizou em Constituições internacionais, organizações e procedimentos ${ }^{4}$.

No entanto, com o fim da ordem mundial bipolar e a ascensão dos Estados Unidos à potência mundial hegemônica, surge uma alternativa àquela visão de uma Constituição cosmopolita no sentido kantiano. No contexto de uma transição para uma constelação pós-nacional da sociedade mundial, o projeto kantiano de uma ordem cosmopolita depara-se com o protesto dos que afirmam a precedência social e ontológica do poder sobre o direito, bem como dos que se apresentam em nome de um ethos mundial liberal no lugar do direito. Segundo essa interpretação, o direito internacional não tem nenhum poder imperativo (obrigação, imposição, sanção), pois apenas no interior dos Estados seria possível

3 LUBENOW, Jorge A. Democracia e direitos humanos como ideologia: a crítica de Jürgen Habermas à política de poder unilateral norteamericana e à ONU. Aufklärung: Revista de Filosofia, v. 5, n. 3, p. 141-154, 2018.

4 Cf. HABERMAS, Der gespaltene Westen, cap. 8, p. 114, 2004. Veja-se os casos da criação da Liga das Nações (1919) e das Nações Unidas (1945), inspiradas no projeto kantiano da paz perpétua. 
uma domesticação normativa do poder político pelo uso da força (caráter coercitivo do poder de sanção estatal).

Diante da interpretação norte-americana de uma nova ordem mundial baseada no direito imperial, Habermas (2004) indaga se a regulamentação jurídica das relações internacionais deveria ou não ser substituída por uma eticização da política mundial determinada pela superpotência; se o direito ainda seria o meio adequado para realizar os objetivos da garantia da paz e da segurança internacional, da implementação da democracia e dos direitos humanos; enfim, se a constitucionalização do direito internacional ainda teria alguma chance ${ }^{5}$. Pois o exemplo da invasão do Iraque pelo governo norte-americano teria mostrado o quanto uma potência decidida a fazer guerra para garantir os interesses nacionais pode de modo imperial ignorar o direito internacional estabelecido e marginalizar uma organização mundial como as Nações Unidas. Esse exemplo teria escancarado a relação assimétrica entre poder e direito, a ausência da relação forte entre poder e direito no âmbito internacional, e mostrado que a reciprocidade entre poder estatal e direito encontrada nos Estados nacionais encontrar-se-ia ausente na esfera internacional. ${ }^{6}$ Também na obra Zwischen Naturalismus und Religion, Habermas (2005) questiona no capítulo 11 sobre as chances de uma Constituição política para uma sociedade mundial pluralista pacificada:

Após a invasão do Iraque, e tendo em vista as violações do direito das gentes, que vieram na sua esteira, as chances de um projeto destinado a promover um "estado de cidadania mundial" cosmopolita não são piores do que em 1945, após a catástrofe da Segunda Guerra Mundial, nem mais remotas do que em 1989/90, quando teve fim a constelação formada

\footnotetext{
5 Ibid., Parte IV, cap. 8. Em nota de rodapé Habermas agradece ao Professor Hauke Brunkhorst pelas contribuições estimulantes durante a preparação do texto.

6 Ibid., cap. 8, p. 119.
} 
por um poder bipolar. Isso não significa, no entanto, que as atuais chances sejam boas 7 .

Em contrapartida à interpretação imperialista do direito, Habermas (2005) reafirma o constitucionalismo kantiano na defesa de um pacifismo apoiado no direito, argumentando que a criação da Liga das Nações (1919) e a fundação das Nações Unidas (1945) seriam, duzentos anos depois, processos de aprendizagem institucionais que se orientariam pelo e tenderiam a dar continuidade ao projeto kantiano de uma constituição política mundial ${ }^{8}$. Esse seria um meio mais adequado para a solução de conflitos na arena internacional do que o unilateralismo imperial que apenas visa a hegemonia nos jogos de poder. Por isso, Habermas (2004) insiste na correlação conceitual kantiana entre direito e manutenção da paz, uma vez que a função instauradora da paz do direito estaria entrelaçada com a função de garantir a liberdade de um Estado de direito que os cidadãos poderiam por livre escolha reconhecer como legítimo`. A ideia de uma comunidade pacífica, ainda que não amigável, de todos os povos não seria apenas um mandamento moral, mas sim um princípio do direito ${ }^{10}$.

No entanto, adverte Habermas (2004), o projeto kantiano de constitucionalização do direito internacional só teria alguma chance nas circunstâncias atuais se, do ponto de vista histórico, os Estados Unidos retomassem aquele internacionalismo que representaram após as guerras de 1918 e 1945 e reassumissem o protagonismo no percurso do direito internacional em direção a um Estado cosmopolita;" e se, do ponto de vista conceitual, modificasse a compreensão dos conceitos centrais da

\footnotetext{
HABERMAS, Jürgen. Zwischen Naturalismus und Religion. Frankfurt: Suhrkamp, 2005, cap. 11, p. 324. Todas as traduções são do autor.

8 Ibid, p. 324.

9 Sobre isso, ver texto anterior de HABERMAS: "Kants Idee des ewigen Friedens - aus dem historischen Abstand von 200 Jahren", In: Die Einbeziehung des Anderen: Studien zur politischen Theorie. Frankfurt: Suhrkamp, 1996, cap. 7, p. 192-236.

10 Cf. HABERMAS, 2004, , p. 120.

1 Ibid, p. 114.
} 
proposta kantiana de constituição de uma república mundial, tais como "república mundial”, "soberania nacional”, "direito estatal”, "nação” e "cidadão". Embora Kant tivesse dado um passo importante modificando a compreensão do direito internacional de um direito de Estados para um direito cosmopolita, a simples extensão da constitucionalização do direito para o âmbito das relações interestatais seria insuficiente para reequacionar a atual relação assimétrica entre o poder e o direito na esfera internacional, e para atenuar a reincidência em uma condição natural que provocou restrições ao universalismo do direito cosmopolita. Esta é a razão pela qual Habermas, apesar de se orientar pela ideia kantiana de uma ordem de cidadania mundial, busca mostrar que a alternativa kantiana de uma república mundial e de uma federação dos povos seria incompleta e, por isso, precisaria ser reformulada.

Nesse sentido, este artigo trata (1) da contraproposta de Habermas ao modelo de moralização do direito internacional travestido de falso universalismo, utilizando-se da proposta kantiana de uma ordem jurídica cosmopolita de paz perpétua, entretanto reconstruída conceitualmente à luz das circunstâncias históricas atuais, resultando (2) na proposta de constituição política para uma sociedade mundial pluralista em termos de uma democracia constitucional transnacional que retoma aspectos da teoria discursiva do direito e da democracia deliberativa.

\section{A reconstrução habermasiana do projeto kantiano de uma ordem jurídica cosmopolita}

Embora se oriente pela ideia kantiana de uma ordem de cidadania mundial, Habermas busca mostrar que a alternativa kantiana de uma república mundial e de uma federação dos povos enfrenta dificuldades conceituais mostrando-se inadequada para as atuais experiências históricas e, caso não queira perder o contato com uma situação mundial que 
se modificou por completo, precisa ser reconstruída. ${ }^{12}$ Essa reconstrução da proposta kantiana de juridificação da ordem global orienta-se, em um primeiro momento, pela modificação da compreensão dos conceitos-chave de "república mundial", "soberania nacional", "direito estatal", "nação" e "cidadão".

\subsection{0 conceito kantiano de república mundial}

O conceito de república mundial está inscrito na discussão kantiana sobre relações internacionais e direito cosmopolita, e é tematizado especialmente nas obras A paz perpétua (1795) e Doutrina do direito (1797) ${ }^{13} . \mathrm{Na}$ obra sobre a paz perpétua, no segundo artigo definitivo para a paz perpétua, Kant trata da constituição de uma "federação de estados livres" e a formação de uma "liga dos povos" como garantia do estado de paz." Para Kant, os conflitos entre estados não devem ser resolvidos pela guerra, o direito não deve ser buscado por meio da guerra, não se deve empregar a força no estabelecimento de um estado legal (condição de um estado natural, não jurídico). ${ }^{15}$ Para resolver conflitos, deveria existir uma federação de tipo especial, também denominada de "federação da paz" (foedus pacificum), capaz de conduzir à um pacifismo jurídico, à paz perpétua. Este estado de paz permanente é o ideal normativo, o fim último do direito das gentes e

\footnotetext{
12 No que segue, Habermas se apoia no seu ensaio anterior "Das Kantische Projekt und der gespaltene Westen", In: Der gespaltene Westen. Frankfurt: Suhrkamp, 2004, parte IV, p. 200-209. Especialmente a revisão conceitual sobre soberania externa e interna dos estados

13 KANT, Immanuel. A paz perpétua: um projeto filosófico. Trad. Artur Morão. Universidade da Beira Interior, Portugal, 2008; KANT, I. Doutrina do direito. 2. ed. Trad. Edson Bini. São Paulo: Ícone, 1993, segunda parte, seção II [Do direito das gentes] e seção III [Direito cosmopolita]. Para uma abordagem mais aprofundada do direito internacional e do cosmopolitismo kantiano, sugiro três excelentes obras: LIMA, Francisco J. G. A teoria kantiana das relações internacionais: pressupostos morais, jurídicos, políticos. Porto Alegre: Editora Fi, 2015, especialmente cap. 4.4 [Federação dos povos, estado dos povos e república mundial], p. 119-126; NOUR, Soraya. À paz perpétua: filosofia do direito internacional e das relações internacionais. São Paulo: Martins Fontes, 2004; BRUNKHORST, (ed.). Demokratie in der Weltgeselschaft. Baden-Baden: Nomos, 2009.

14 Cf. KANT, 2008, p. 15-19.

15 Cf. KANT, Doutrina do direito, 1993, p. 203-205.
} 
que adquire forma concreta na constituição de uma república mundial' ${ }^{16}$. Como escreve Lima, "a pretensão inicial de Kant... é que os Estados formem um Estado de povos que gradativamente ganhe proporções planetárias e chegue a se transformar numa república mundial"17.

No entanto, contrapõe Habermas, o problema é que a república mundial (regulada pela constituição) não seria uma mera extensão da pacificação cosmopolita da condição natural entre os estados baseado no direito internacional (regulado por contrato) sendo, por isso, desprovida de um dispositivo jurídico constitucional, e permanecendo dependente da filiação moral dos governos. Para Habermas, uma aliança dos povos precisa ser institucionalizada, modificando o estatuto das relações internacionais reguladas por contrato pelo estabelecimento de uma relação interna de base constitucional' ${ }^{18}$.

\subsection{Alternativa habermasiana: modificações conceituais}

Como esboço de uma alternativa conceitual para o conceito kantiano de república mundial, a partir das estruturas atualmente existentes

\footnotetext{
16 Escreve Kant: “Uma paz perpétua (fim último de todo o direito das gentes) é, indubitavelmente, uma ideia impraticável. Entretanto, os princípios políticos que tendem a realizar estas reuniões de cidades, como para favorecer a aproximação sem fim a esse estado de paz perpétua, não são impossíveis" (KANT, 1993, p. 200).

17 LIMA, 2015, p. 123.

18 HABERMAS, Die Einbeziehung des Anderen, cap. 7, p. 208, 1996. Esse argumento crítico de Habermas já está presente na Filosofia do Direito de Hegel: "A concepção kantiana de uma paz eterna assegurada por uma liga internacional que afastaria todos os conflitos e regularia todas as dificuldades como poder reconhecido por cada Estado, impossibilitando assim a solução que a guerra traz, supõe a adesão dos Estados; teria de se assentar em motivos morais subjetivos ou religiosos que dependeriam sempre da vontade soberana particular e estaria, portanto, sujeita à contingência". HEGEL, Georg W. F. Princípios da filosofia do direito. 2. ed., Trad. Norberto Lima. São Paulo: Ícone, 2005, p. 269. No entanto, julgo não ser plausível detalhar aqui as diferenças entre Hegel e Habermas na crítica ao projeto kantiano de paz perpétua; isso pode ser tema de outro artigo. Pode-se afirmar, todavia, que diferentemente de Hegel, Habermas não descarta, mas reconstrói atualizando a proposta kantiana, elaborando uma nova fundamentação de uma ordem constitucional cosmopolita em vista de uma república mundial a partir do direito procedimental e da democracia deliberativa.
} 
seriam necessárias, para Habermas, ao menos quatro modificações conceituais da teoria política.

a) Modificar a compreensão de república mundial. Para Habermas, a ideia de um Estado cosmopolita, que se desloca de um direito de Estado ao direito dos cidadãos do mundo, adquire em Kant a forma concreta na constituição de uma república mundial, assume o sentido cosmopolita da construção de uma república mundial. Escreve Habermas:

A ideia de uma república mundial, é claro, não se esgota na noção de uma ordem jurídica supranacional à qual os poderes estatais se submetem, em analogia com o direito de Estado ou de cidadania de pessoas individuais. Com os instrumentos repressivos de um monopólio despótico da força, uma "monarquia universal" também poderia conduzir a uma pacificação da sociedade mundial. A ideia de um Estado cosmopolita é mais ambiciosa porque transfere a positivação dos direitos humanos e de cidadania da esfera nacional à internacional. O núcleo inovador desta ideia reside na consequência de uma reformulação do direito internacional, enquanto direito de Estados, em um direito cosmopolita, enquanto direito de indivíduos ${ }^{19}$.

No entanto, Habermas adverte que o recurso do moderno contrato social (da moderna formação de Estados a partir do estado de natureza) "não serviria como analogia", uma vez que agora os cidadãos dos Estados já usufruiriam de direitos e liberdades garantidos juridicamente. Deverse-ia, assim, caminhar do direito de Estado para o direito dos cidadãos do mundo. Escreve Habermas:

Assim como outrora os indivíduos, mediante o sacrifício de sua liberdade natural, uniram-se em uma coletividade organizada

19 HABERMAS, Der gespaltene Westen, cap. 8, p. 121-122, 2004. 
em torno do Estado, assim também os Estados, mediante o sacrifício de sua soberania, devem convergir para a "república cosmopolita sob um dirigente". Se antes o Estado fora a solução, agora também o Estado dos Estados, o Estado dos povos, deve trazer a solução. Essa analogia, mesmo vista sob as premissas do direito racional de Kant, é enganosa [...]. O currículo (Curriculum) que os Estados e seus cidadãos devem percorrer na transição do direito internacional clássico a um Estado cosmopolita é de modo algum análogo, mas complementar ao caminho que os cidadãos de Estados de direito democráticos concluíram retrospectivamente no processo de legalização de um poder estatal que de início agia sem amarrar ${ }^{20}$.

Diferentemente de Kant, para Habermas (2004) a transição do direito internacional para o direito cosmopolita não poderia avançar em linha reta, pois a constitucionalização do poder estatal sela a inversão da constelação inicial de um direito instrumentalizado pelo poder. Se pela lógica do contrato social a racionalização da dominação realizar-se-ia a partir de um poder estatal constituído, pela lógica da Constituição a racionalização da dominação realizar-se-á de modo que todo poder se originaria da vontade autônoma dos cidadãos, formada racionalmente ${ }^{21}$. Escreve Habermas:

A constitucionalização do direito internacional não pode ser compreendida como a continuação lógica da domesticação constitucional de um poder estatal que surgiu naturalmente. O ponto de partida para a juricidização pacificadora das relações internacionais é constituído por um direito internacional que, do ponto de vista da sua forma clássica, inverte a relação entre Estado e Constituição ${ }^{22}$.

\footnotetext{
20 Ibid., p. 128-129.

21 Ibid., p. 130-131.

22 lbid., p. 131.
} 
Uma constitucionalização do direito internacional "se contrapõe" à genealogia do Estado constitucional em virtude da precedência usufruída pelas relações horizontais entre membros sobre as capacidades organizadas de ação, da formação não-hierárquica de uma comunidade de sujeitos coletivos de ação para organizações internacionais capazes de ação, de uma ordem cosmopolita. Exemplos nessa direção - da evolução do direito de Estado ao direito cosmopolita - seriam as organizações internacionais como as Nações Unidas (ONU), a Organização Mundial do Comércio (OMC) e a União Europeia. No campo político, os Estados-membros das Nações Unidas cedem ao Conselho de Segurança a competência para intervir em questões de segurança internacional, de proteção dos direitos humanos e até de proteção dos cidadãos contra os próprios governos. Também a Constituição da União Europeia faz referência aos cidadãos dos Estadosmembros. Ao mesmo tempo que os atores estatais devem manter uma posição forte em uma ordem global de direito e paz, os indivíduos são os genuínos detentores do status cosmopolita ${ }^{23}$.

Com esse desenho de uma política interna mundial sem governo mundial, no âmbito de uma organização mundial capaz de garantir a paz e a realização dos direitos humanos, Habermas quer mostrar que o projeto kantiano pode ser desenvolvido como alternativa conceitual para além da "república mundial" ou do "Estado dos povos"; de que o Estado constitucional ampliado globalmente não é o único a satisfazer as condições abstratas de um Estado cosmopolita ${ }^{24}$.

Segundo Habermas (2005), a inovação de Kant teria sido a passagem do direito das gentes (Völkerrecht), centrado nos Estados, para o direito dos cidadãos do mundo (Weltbürgerrecht), abrindo caminho para tirar a Constituição cidadã do plano do Estado nacional e projetá-la para um plano global, o que abriu o caminho para o conceito de uma constitucionalização do direito das gentes. Trata-se de uma reformulação do

\footnotetext{
23 Ibid., p. 133.

24 lbid., p. 135.
} 
direito internacional, visto como direito de Estados, mas estendido para um direito de cidadãos do mundo, um direito de indivíduos. No entanto, o problema de Kant teria sido a simples extensão da constitucionalização do direito das nações para o âmbito das relações interestatais; translado denominado por Habermas de "concepção fraca". 25

b) Modificar o conceito de soberania nacional para pós-nacional. Trata-se de adaptar o conceito de soberania do Estado às novas formas de governar que se estendem para além do Estado nacional. A soberania estatal diz respeito à capacidade do Estado de conservar a ordem, a segurança e a proteção no limite das fronteiras territoriais e na capacidade de conservar a identidade e a forma de vida política da coletividade. Disso resulta uma autodeterminação democrática traduzida em termos de soberania do povo. No entanto, o conceito de soberania estatal altera seu significado quando não consegue mais atender a segurança e o bem-estar da população e necessita entrar em um trabalho de cooperação com outros Estados. As condições de uma sociedade mundial exigem agora da soberania estatal a capacidade e a disposição em participar da resolução de problemas que se apresentam no plano regional e global e que só podem ser resolvidos no quadro de organizações internacionais ou supranacionais ${ }^{26}$.

c) Modificar a compreensão do interno direito coercitivo estatal para o externo direito de sanção supranacional. Trata-se de rever o nexo conceitual que liga o monopólio estatal do poder ao direito coercitivo considerando que o direito supranacional tem o respaldo de potenciais de sanção estatais. Os Estados nacionais repassam às organizações supranacionais, não o monopólio do poder, mas o direito de impor sanções e, com isso, se altera a relação entre o direito estatal (coercitivo e com meios de aplicação legítima da força) e o direito instituído no nível

25 Cf. HABERMAS, Zwischen Naturalismus und Religion, cap. 11, p. 326, 2005.

26 Ibid., p. 331-332. 
supraestatal (que dispõe de competências de sanção). Embora o monopólio do poder continue nas mãos dos Estados nacionais, estes cedem às organizações internacionais, ao menos formalmente, o direito de decidir sobre a aplicação do direito ou até do uso do poder militar. O Conselho de Segurança da ONU e a União Europeia seriam exemplos da primazia de normas jurídicas supranacionais com anuência dos Estados-membros ${ }^{27}$.

d) Modificar a compreensão que as nações e os cidadãos têm de si mesmos. Trata-se de modificar, tanto no nível interno como no nível externo, a compreensão dos papéis das partes contratantes (Estados e cidadãos). A autocompreensão de ambos, que se dava no âmbito nacional, precisa transformar-se em consciência de membros (com direitos e deveres) de uma organização supranacional. ${ }^{28}$

\subsection{Sobre as chances do projeto kantiano reformulado à luz das circunstâncias atuais}

Reformulando o projeto kantiano à luz das circunstâncias atuais, Habermas (2005) ainda acredita no sucesso desse projeto que envolve uma substância democrática das formas de socialização política transnacionais. Nesse sentido, apresenta a contraproposta de uma política mundial sem governo mundial e que poderia ser configurada em um âmbito global como um sistema de vários níveis. Diferentemente do direito das gentes (centrado em Estados), essa nova estrutura de uma sociedade mundial politicamente constituída - uma sociedade dos cidadãos do mundo constitucionalizada -, poderia ser caracterizada por três arenas e três tipos distintos de atores: ${ }^{29}$

\footnotetext{
27 lbid., p. 324.

28 Ibid., p. 333-334.

29 Ibid., p. 334-340.
} 
a) Arena supranacional: ocupada por um único ator, uma organização mundial, sem caráter estatal, capaz de agir em âmbitos políticos bem delimitados; organização mundial que poderia assumir a clássica função da garantia da paz (direito, segurança e liberdade), antes atribuída aos Estados, através da implementação global dos direitos humanos. As Nações Unidas, por exemplo, cumprem as funções fundamentais de preservar a segurança internacional e implantar os direitos humanos. A formação da opinião pública da organização mundial em uma esfera pública mundial mobilizada deve ser reconectada aos processos de comunicação nos parlamentos nacionais, bem como estar aberta à participação de organizações não governamentais. E, enquanto não existe algo como um "parlamento mundial" (ver adiante $6 \mathrm{c}$ ), a organização mundial deve apoiar-se nos centros de poder organizados na forma de Estados. Os Estados continuam sendo - ao lado dos indivíduos - sujeitos de um direito dos povos alterado para direito dos cidadãos do mundo. De acordo com as "metas de desenvolvimento" das Nações Unidas, os Estados precisam conservar uma posição singular como membros da comunidade internacional por dois motivos: primeiro, a proteção dos direitos fundamentais dos cidadãos do mundo não se circunscreve mais a direitos fundamentais liberais e políticos, mas se estende às condições materiais de vida; segundo, redes e organizações transnacionais se entrecruzam e exigem informações e acordos de coordenação e regulação de problemas que ultrapassam as fronteiras (padronização de medidas, regulação das telecomunicações, prevenção de catástrofes, contenção de epidemias, combate ao crime organizado, bem como questões políticas de energia, meio ambiente, finanças e economia). Apesar das redes políticas existentes, faltaria o quadro institucional e atores com competências legislativas, bem como os atores coletivos capazes de implementar na prática tais decisões.

b) Arena transnacional: uma arena intermediária ocupada por global players, capazes de firmar acordos não fixos e equilíbrios 
de poder flexíveis e negociar compromissos de implementação. Seria necessário um sistema de negociações capaz de suplantar os desníveis de uma sociedade altamente estratificada, os desequilíbrios ecológicos e as tensões do pluralismo cultural, problemas que excedem e não podem ser resolvidos sem mais dentro das fronteiras dos Estados nacionais. Nesse sentido, as relações internacionais continuariam a existir, embora de forma alterada, uma vez que nem o global player mais forte teria permissão para utilizar a guerra como recurso para resolução de conflitos. No entanto, ainda não há, com exceção dos Estados Unidos, atores (nacionais) capazes de ação transnacional.

c) Arena nacional: ocupada por Estados nacionais. Embora continuem a participar como atores nas arenas internacionais, os Estados nacionais encontram-se cada vez mais pressionados pelas exigências funcionais da globalização econômica que impactam espaços de decisão e legitimação locais. Em contrapartida, os Estados nacionais firmariam acordos de cooperação regionais (preponderantemente acordos "econômicos") que, no entanto, continuariam frágeis do ponto de vista da capacidade de ação transnacional e global. Essa capacidade de ação e legitimação no âmbito transnacional apenas seria alcançada se os Estados nacionais se juntassem em associações que ultrapassassem as formas intergovernamentais. Embora até agora isso ainda não tenha sido alcançado, estaria em andamento na Europa uma "união política" que, em parte, já conseguiria demandar um ator coletivo regional com peso político global, o que poderia servir de exemplo para as outras regiões. Escreve Habermas:

A União Europeia poderia assumir o papel de um modelo para outras regiões porque ela consegue harmonizar em um nível de integração superior os interesses de Estados nacionais que já eram independentes anteriormente, gerando, por este caminho, um ator coletivo numa escala não conhecida antes. Entretanto, a União Europeia só poderá servir de modelo para a estruturação de capacidades de ações regionais caso ela 
consiga atingir um grau de integração política que permita à União perseguir, seja internamente, seja no exterior, políticas comuns legitimadas democraticamente ${ }^{30}$.

\subsection{Tendências históricas}

Nos três níveis acima (1.3a, 1.3b e 1.3c) mostram-se duas tendências históricas que vêm ao encontro desse projeto de uma Constituição de cidadãos do mundo (Habermas fala em "degraus da constitucionalização"): a reforma das Nações Unidas e a integração política da união europeia.

a) Primeira tendência: reforma das Nações Unidas. As pressuposições normativas idealizadoras do projeto kantiano de constitucionalização internacional do direito das gentes encontram ressonância em práticas e procedimentos já exercitados, tais como na reforma da ONU em andamento. O desdobramento atual do direito internacional mostra-se como uma constitucionalização fomentada pelos Estados em uma ordem constitucional internacional, com o objetivo de fortificar o papel jurídico das pessoas de direito reposicionadas em termos de direito internacional como cidadãos do mundo. É nesse sentido que aponta a reforma da organização mundial Nações Unidas (Carta da ONU), que inova em quatro pontos: [a Carta das Nações Unidas] interliga a garantia da paz mundial com a implementação dos direitos humanos; autoriza o emprego de sanções e intervenções para impedir a violência, fortalecendo a primazia das medidas do Conselho de Segurança sobre as posições de superpotências que insistem no direito de ações preventivas; relativiza a soberania dos Estados nacionais em vista da implementação de um direito de status superior, da paz

$30 \quad$ Ibid, p. 338. 
mundial e da segurança coletiva; postula a primazia do direito internacional, reforçando a importância das Nações Unidas ${ }^{31}$.

b) Segunda tendência: integração política da união europeia. Na obra Zur Verfassung Europas, Habermas (2011) analisa no capítulo 2 o papel civilizador da integração política da União Europeia à luz de um cosmopolitismo de alcance mais amplo ${ }^{32}$. A resolução do problema da regulamentação política de um desequilíbrio do sistema econômico que ultrapassa as fronteiras nacionais requer uma juridificação democrática para além das fronteiras nacionais, nos mesmos moldes da constitucionalização na unificação europeia. Nesse sentido, a proposta de Habermas tenta transpor as inovações que serviram de orientação para a juridificação democrática da União Europeia para uma democracia constitucional transnacional. Nesse sentido, a forma histórica da União Europeia poderia servir de imediato para delinear uma sociedade constituída politicamente. Desenvolvida a partir do exemplo da União Europeia, a ordem política mundial poderia ser concebida como uma continuidade da juridificação democrática do poder estatal e europeu. Uma Constituição democrática da sociedade mundial exige a modificação dos pilares da coletividade democrática que serviram de referência a União Europeia. Agora, de modo similar, o objetivo é a constituição de uma comunidade de cidadãos do mundo. Uma cooperação constituinte entre cidadãos e Estados pode indicar o caminho pelo qual a comunidade de Estados já existente poderia ser complementada com uma comunidade cosmopolita ${ }^{33}$.

\footnotetext{
31 Sobre críticas e reformas da ONU, ver: HABERMAS, Der gespaltene Westen, 2004, cap. 7, p. 107; 169-173; HABERMAS, Ach Europa: Kleinen Politischen Schriften. Frankfurt: Suhrkamp, 2008, cap. 9, p. 121.

32 Cf. HABERMAS, Jürgen. Zur Verfassung Europas: Ein Essay. Berlin: Suhrkamp, 2011, cap. 2, p. 82.

33 Resta saber se Habermas ainda mantém este diagnóstico esperançoso de antes da crise da integração política europeia a partir do fracasso do modelo de federalismo executivo denunciado posteriormente na obra: HABERMAS, Jürgen. Im Sog der Technokratie. Berlin: Suhrkamp, 2013. Sobre os problemas da integração política europeia e o novo perfil econômico-liberal da Europa, ver: LUBENOW, O Ocidente dividido: o impacto da globalização econômica neoliberal na integração política da União Europeia. Aufklärung: Revista de Filosofia, 2017, v. 4, n. 3, p.
} 


\subsection{Limites do aprofundamento democrático das instituições transnacionais}

Apesar de pensar uma corrente de legitimação desde os Estados nacionais, passando por regimes regionais até chegar ao âmbito de uma organização mundial, (a) o "deficit de legitimidade" (Habermas fala em "legitimidade reduzida", "legitimação fraca" ou "legitimação indireta") das instituições transnacionais e instituições supranacionais existentes seria um dos principais obstáculos para a compreensão da legitimidade democrática de uma democracia constitucional transnacional. a) (b) Essa "legitimação fraca" poderia ser identificada também nas atuais formas da solidariedade civil e da esfera pública mundial b) no (c) apelo moral aos direitos humanos c), na (d) lacuna de responsabilidade parlamentar d) e no (e) caso das Constituições supranacionais sem Estado e). Apenas depois disso será possível elucidar a proposta de uma constituição política para uma sociedade mundial pluralista a partir da constitucionalização do direito internacional (como veremos adiante em 2.1 e 2.2).

a) Déficit de legitimação das organizações transnacionais e instituições supranacionais. Aqui Habermas se defronta com o problema da legitimidade que é necessária, por um lado, mas ao mesmo tempo mostra um déficit de legitimação das decisões políticas em organizações internacionais, por outro lado. ${ }^{34} \mathrm{As}$ decisões políticas de instituições supranacionais alimentam-se de acordos recíprocos entre Estados soberanos, cuja medida de legitimação transnacional ultrapassa, desproporcionalmente, as Constituições democráticas dos mesmos Estados. Ou seja,

119-134; LUBENOW, A redefinição do perfil político da Europa de estatal-social para econômico-liberal: uma análise crítica a partir de Jürgen Habermas. Aufklärung: Revista de Filosofia, v. 3, n. 2, p. 95-112, 2016; LUBENOW, The paradox of technocratic democracy and the democratic deficit of European Union Institutions by Jürgen Habermas. Aufklärung: Revista de Filosofia, v. 2, n. 2, p. 103-122, 2015.

34 Sobre isso, ver: BRUNKHORST, Legitimationskrisen: Verfassungsprobleme der Welgeselschaft. Baden-Baden: Nomos, 2012; BRUNKHORST (ed.), Demokratie in der Weltgeselschaft. BadenBaden, Nomos, 2009, p. 185-193. 
existe uma desproporção (desacoplamento, perda da ancoragem) entre a legitimidade do Estado (gerada no interior dos Estados nacionais) e legitimidade supranacional (aquela gerada pelos acordos interestatais e organizações transnacionais). É nesse sentido que a comissão de reforma da ONU sugere incluir nas deliberações organizações não governamentais como uma tentativa de aumentar o grau de aceitabilidade das decisões da organização mundial na esfera pública mundial. No entanto, segundo Habermas, tais reformas não seriam suficientes para superar o abismo existente e criar uma ligação adequada entre a legitimidade gestada no interior de um Estado e a legitimidade das decisões supranacionais ${ }^{35}$. A questão é saber se a forma de legitimação que resulta do Conselho de Segurança e do Tribunal Penal Internacional seria capaz de superar esse deficit. Essa questão, no entanto, só poderia ser colocada e respondida em dois planos distintos: o supranacional e o transnacional. O plano supranacional ocupar-se-ia com tarefas que são mais de cunho jurídico do que político, uma vez que o direito e a política internacional se orientam pela linha dos direitos humanos. O que poderia conferir uma legitimação suficiente às decisões de duas instituições centrais (Conselho de Segurança e o Tribunal Penal) capazes de serem inseridas em uma esfera pública política mundial é o fato de ambas contarem com a concordância quanto aos objetivos políticos da concepção de segurança, quanto à base legal das convenções do direito internacional das gentes e quanto ao modo pelo qual uma organização mundial reformada processa as suas tarefas; nesse caso, poderiam obter o reconhecimento e a legitimidade, poderia alimentar-se dessa força normativa desses princípios e procedimentos conforme a justiça.

Segundo Habermas, é notório que as decisões sobre a guerra e a paz, as infrações de segurança coletiva e as violações dos direitos humanos

35 Cf. HABERMAS, 2005, p. 356. 
chamam a atenção, provocam reações espontâneas, suscitam um sentimento comum de indignação moral e ecoam criticamente em uma esfera pública gerando "um sopro de solidariedade de cidadãos do mundo" ${ }^{36}$. No entanto, trata-se de uma esfera pública muito fraca. Essa moral de uma justiça universalista seria, no plano transnacional, por demais estreita para lidar com acordos regulativos e questões de distribuição. Essa carência de legitimação só poderia ser preenchida pelo caminho democrático que, no entanto, continua fechado enquanto não se abre a possibilidade de uma ordem constitucional mundial. Esse "déficit de legitimação" (perda do controle político da sociedade sobre si mesma) no plano supranacional é aqui o verdadeiro problema das novas formas de governar das organizações internacionais que ultrapassam as fronteiras do Estado nacional.

b) Ausência de solidariedade civil e de esfera pública mundial "forte". Se é possível encontrar indícios de transposição do direito supranacional e da cidadania mundial no âmbito institucional das Nações Unidas, não seria possível encontrar, entretanto, indícios da terceira inovação: uma ampliação da solidariedade civil mundial, um alargamento da solidariedade civil para além das fronteiras dos Estados nacionais. Do ponto de vista da juridificação democrática, a dinâmica da política mundial das Nações Unidas exigiria um reacoplamento entre o Parlamento mundial e a formação da opinião e da vontade dos cidadãos mundiais. No entanto, Habermas tem razões empíricas para duvidar da extensão da solidariedade civil para o âmbito mundial. O ceticismo em relação à transnacionalização da soberania popular deve-se às capacidades limitadas de ação de uma esfera pública mundial esporádica, que se inflama de forma pontual em alguns acontecimentos, e que não se estrutura de modo mais sistemático e duradouro. Caso adotasse o formato mundial, a ampliação transnacional da solidariedade civil acabaria no vazio, pois a vinculação dos cidadãos do mundo por meio de uma esfera pública mundial não está mais inserida no

36 Ibid., p. 358. 
contexto de uma cultura política comum ${ }^{37}$. Os cidadãos do mundo não formam um coletivo que permaneceria unido pelo interesse político na autoafirmação de uma forma de vida. Não obstante a ausência de uma cultura política compartilhada, mesmo assim poderiam ser compartiIhados interesses bastante abstratos considerados importantes para a sobrevivência, tais como nível de segurança mundial, nível de exigência dos sistemas educacionais, de saúde e de transporte, equilíbrio ecológico, recursos naturais, entre outros. $\mathrm{Na}$ ausência de uma solidariedade civil ampliada/transnacionalizada, e sem esfera pública mundial "forte"38, Habermas parece recorrer a uma perspectiva moral, a da "solidariedade moral", baseada nos direitos fundamentais, (direitos subjetivos, direitos humanos), e que poderia ser compartilhada pela população mundial:

Estamos todos acostumados a lidar com situações cotidianas em que nos sentimos comprometidos a ser solidários com estranhos, com todos aqueles que possuem um semblante humano. Somente esse universo moral de todas as pessoas responsáveis por suas ações, e que Kant chamou de "reino dos fins", é plenamente inclusivo: ninguém é excluído. A injustiça que pode acometer qualquer pessoa, a violação sofrida por não importa qual pessoa, incita nossa sensibilidade moral e provoca em nós uma indignação moral ou uma necessidade de prestar auxílio. Desse sentimento se nutrem os juízos morais, que podem ser racionalmente fundamentados se a adoção recíproca de perspectivas levar a uma percepção suficientemente descentralizada do conflito e à consideração igual de todos os interesses em questão ${ }^{39}$.

37 Cf. HABERMAS, Zur Verfassung Europas, cap. 2, p. 89, 2001.

${ }_{38}$ Sobre os discursos críticos, ver: LUBENOW, Hauke Brunkhorst e o conceito de solidariedade democrática como crítica à esfera pública pós-nacional de Jürgen Habermas. Veritas: Revista de Filosofia (PUC-RS), v. 58, n. 1, p. 118-130, 2013; LUBENOW, A categoria de esfera pública em Jürgen Habermas. 2.ed. Curitiba: CRV, 2015; e as coletâneas: LUBENOW; SILVA; AZEVEDO, Habermas 80 anos. Rio de Janeiro: Tempo Brasileiro, 2010, 2v; LUBENOW; SILVA. Esfera pública 50 anos depois. Dossiê Revista Problemata, v.3, 2012.

39 HABERMAS, 2011, cap. 2, p. 91. 
c) Apelo moral aos direitos humanos. Diz Habermas: "Nesse momento, a precariedade do estado de cidadania mundial requer grande sensibilidade". ${ }^{\circ}$ Embora adote a perspectiva do direito e da política quando trata das tarefas das Nações Unidas, Habermas não deixar de notar que, na aplicação jurídica, as dimensões políticas da proibição do uso da violência e dos direitos humanos são interpretadas como normas fundamentadas em bases morais. A garantia da justiça, da paz e dos direitos humanos podem ser traduzidos, não no médium da política, mas do direito. Assim escreve:

Desconsiderando sua forma jurídica, esses direitos subjetivos prioritários têm um conteúdo exclusivamente moral porque os direitos humanos circunscrevem exatamente a parte do universalismo moral que pode ser traduzida no médium do direito coercitivo. Isso explica a natureza antes jurídica do que política das decisões que estariam em causa no espaço das Nações Unidas reformadas segundo nossa interpretação ${ }^{41}$.

No entanto, conforme o primeiro capítulo da obra Zur Verfassung Europas (2011), que trata do conceito de dignidade humana e a utopia realista dos direitos humanos, embora as experiências de violação da dignidade humana tenham nas últimas décadas conseguido provocar críticas de indignação capazes de impulsionar a eficácia retórica e a implementação da política dos direitos humanos no nível global, Habermas acentua que a pretensão cosmopolita do papel dos direitos humanos não poderia se esgotar em uma crítica moral de indignação moral diante de relações injustas de uma sociedade altamente desigual, mas seria preciso

40 HABERMAS, Jürgen. Zeit der Übergänge. Frankfurt: Suhrkamp, 2001, cap. 2, p. 38.

${ }^{41}$ HABERMAS, 2011 cap. 2, p. 91-92. 
também que os direitos humanos fossem incorporados institucionalmente em uma sociedade mundial constituída politicamente ${ }^{42}$.

\author{
d) Lacuna de responsabilidade parlamentar. Outra dificuldade \\ é a de reconectar uma vontade mundial, expressa em uma \\ esfera pública ou solidariedade civil, comum a um Parlamento \\ mundial. Escreve Habermas:
}

Não podemos esperar dos cidadãos do mundo uma formação coletiva da vontade em sentido propriamente político. As eleições para o Parlamento mundial expressariam apenas o "sim" e o "não" moralmente fundamentados na aplicação supranacional de princípios e normas morais presumivelmente compartilhados ${ }^{43}$.

A desobrigação das Nações Unidas diante de questões políticas em sentido estrito, especialmente medidas políticas distributivas, tem um outro lado: ela revela o problema da legitimação fraca ou indireta. No âmbito da política interna mundial realizada transnacionalmente, atores

\footnotetext{
42 Ibid., Prefácio, p. 11. Nesse ponto, Pinzani chama a atenção para uma mudança importante na fundamentação habermasiana da teoria democrática e justa de uma sociedade global, na qual praticamente não haveria mais espaço para aquela teoria do discurso onde uma comunidade discursiva global decide livremente sobre quais direitos fundamentais garantir-se reciprocamente. Esta ideia teria sido substituída por uma ideia transcendente de justiça que aguarda sua realização jurídica e é justificada agora por razões morais, o apelo à dignidade de cada um que se impõe como uma força superior a qualquer outro tipo de argumento. Esta mudança importante aproximaria Habermas daqueles defensores das teorias normativas da justiça que antes eram rechaçadas por Habermas. Cf. PINZANI, "Apresentação à edição brasileira". In: Jürgen Habermas: sobre a Constituição da Europa. São Paulo: Ed. UNESP, 2012, p. XXX. No entanto, diferente de Pinzani, penso que o recurso aos direitos humanos apenas fornece uma alternativa normativa dada a ausência de uma esfera pública e solidariedade civil transnacional forte. Nesse sentido, o deslocamento na fundamentação da filosofia política não significaria tanto um deslocamento para uma teoria mais transcendente de justiça, como acredita Pinzani, mas apenas o último recurso para tentar salvar uma concepção constitucional de democracia, mas que não prescinde do conceito de soberania popular (esfera pública e sociedade civil) que continua fundamental (Cf. adiante 2.1 e 2.2). Habermas não abandonou a concepção discursiva da democracia, do direito e do Estado de direito, mas apenas deslocou a discussão para os problemas da unificação política europeia e da juridificação das relações internacionais. (Cf. HABERMAS, Im Sog der Technokratie, 2013, cap. 4, p. 72).

43 HABERMAS, Zur Verfassung Europas, 2011, cap. 2, p. 92.
} 
capazes de ação global negociam compromissos no âmbito transnacional nos moldes da juridificação democrática da União Europeia. No entanto, nesse âmbito de negociação em relação a tratados internacionais, questões de política externa estão muito menos sujeitas à participação e à legitimação democráticas do que a política interna controlada pelo Parlamento. Comparando com a União Europeia, o ponto fraco da legitimidade de uma política interna mundial é ser desprovida de uma participação direta ou representação de Estados e cidadãos do mundo no Parlamento mundial e, com isso, permanecer entregue às negociações entre os global players ${ }^{44}$.

Em contrapartida, Habermas sugere um modelo nas quais as relações transnacionais entre os global players seriam alteradas, a partir da distribuição do processo político em dois campos diferentes, para além dos Estados e da união entre os Estados, e ramificado nos respectivos trilhos de legitimação. As tarefas da política da segurança global e de direitos humanos passariam para a competência de uma organização mundial composta de tal modo que a necessidade de legitimação reduzida em seus domínios políticos poderia ser satisfeita grosso modo. Apesar de mais fracamente legitimadas, as decisões resultantes de um sistema de negociação transnacional de modo algum seriam confiadas exclusivamente ao jogo da dinâmica internacional do poder ${ }^{45}$. No entanto, essa fundamentação não seria suficiente para preencher a lacuna (Lücke) quanto à responsabilidade parlamentar na corrente de juridificação democrática de uma política interna mundial. A lacuna também é explicada pelo fato histórico de que a condição pretensiosa de condições de vida homogêneas em todo globo não pode ser preenchida por enquanto. Escreve Habermas:

Todo sentimento moral resiste contra a injustiça monstruosa de uma sociedade altamente estratificada em que hoje, bens e oportunidades vitais elementares são desigualmente partiIhados de modo insuportável. Porém, um esquema ainda tão

\footnotetext{
44 Ibid., p. 93-94.

45 Ibid., p. 94.
} 
abrangente para uma ordem mundial que visa à civilização do exercício da dominação política tem de considerar que a não simultaneidade histórica dos desenvolvimentos regionais e a desigualdade socioeconômica correspondente entre as múltiplas modernidades não podem ser eliminadas de hoje para amanhã ${ }^{46}$.

O deslocamento econômico do peso da política mundial em virtude da crise financeira de 2008 provocou, mesmo que tardiamente, a ampliação do grupo das nações industrializadas. Com isso, e considerando a pressão destruidora dos mercados financeiros, dever-se-ia vincular os esforços para a construção de instituições e o estabelecimento de procedimentos que permitissem a formatação de uma política interna mundial, capaz de avaliar, a partir de padrões morais existentes, as estruturas econômicas dominantes e confrontar as instituições existentes e as práticas adotadas com as exigências por mais justiça global. Por fim, adverte Habermas, para adquirir relevância política, essa discussão não deveria ser conduzida apenas na academia, mas no interior de um parlamento mundial, que considera o fator temporal relevante do ponto de vista da justiça ${ }^{47}$.

f) Constituição supranacional e legitimação democrática. Qual a legitimidade de Constituições supranacionais, de "Constituições sem Estado"? A ausência de uma solidariedade ampliada para além das fronteiras nacionais levanta o problema da legitimação de uma Constituição supranacional ${ }^{48}$.

\footnotetext{
46 Ibid., p. 95.

47 Ibid., 2, p. 95-96.

48 Hauke Brunkhorst, Professor de Filosofia e Sociologia da Europa-Universität Flensburg/ Alemanha, analisa a partir de exemplos da ONU, OMC e União Europeia as "Constituições sem Estado", ordens jurídicas sem Estado sob o ponto de vista do déficit democrático de uma "dominação legal sem legislação própria". Sobre isso, ver: BRUNKHORST, Globale Solidarität: Inklusionsprobleme moderner Gesellschaften. In: WINGERT; GÜNTHER (ed.), Die Öffentlichkeit der Vernunft und die Vernunft der Öffentlichkeit: Festschrift für Jürgen Habermas. Frankfurt: Suhrkamp, 2001, p. 605-626; BRUNKHORST, Legitimationskrisen: Verfassungsprobleme der Welgeselschaft. Baden-Baden: Nomos, 2012, cap. 6 [Verfassung ohne Staat?, p. 137-163], cap. 10 [There will be blood: Konstitutionalisierung ohne Demokratie?, p. 253-276], e cap. 12 [Demokratie ohne Staat?, p. 307-312]; e BAST, Jürgen. Das demokratiedefizit fragmentierter Internationalisierung, in: BRUNKHORST (ed.), Demokratie in der Weltgeselschaft. Baden-Baden: Nomos, 2009, p. 185-193.
} 
Os elementos essenciais que se fundiram no Estado nacional (o caráter estatal, a solidariedade de cidadãos e a constituição) não se apresentam da mesma forma e assumem uma configuração diferente fora do Estado nacional. Até agora, mecanismos democráticos de legitimação razoavelmente confiáveis funcionaram apenas no âmbito dos Estados nacionais. Embora a legitimação das constituições supranacionais da democracia deva desvincular-se da dominação organizada nos moldes do Estado, o âmbito normativo das constituições sem Estado deve, todavia, permanecer ligado aos canais de legitimação dos Estados constitucionais. Apesar da constitucionalização do direito internacional guardar um status derivativo, dependente da legitimação alcançada previamente pelos Estados constitucionais de direito democrático, organizações internacionais como a ONU e União Europeia, ao mesmo tempo que não dispõem de meios legítimos de uso da força, exigem a precedência do direito supranacional em relação às ordens jurídicas nacionais. Escreve Habermas:

A constitucionalização do direito internacional, que restringe a dominação, mas é destituída de Estado, só poderá satisfazer as condições de legitimação de um "Estado cosmopolita" quando, seja no plano da ONU ou dos sistemas de negociação transnacional, tiver algum "respaldo" de processos democráticos de formação da vontade e da opinião. Processos estes que... só poderão ser plenamente institucionalizados em Estados constitucionais de direito. A constitucionalização fraca e desprovida de Estado não pode prescindir da legitimação concedida pelas ordens constitucionais centradas em Estados. A parte relativa à organização das constituições assegura aos cidadãos um acesso igualitário às decisões sobre compromissos políticos do governo através de esferas públicas institucionalizadas, eleições, parlamentos e outras formas de participação. Somente no âmbito dos Estados constitucionais democráticos há disposições juridicamente organizadas para uma inclusão equitativa dos cidadãos no processo legislador. Onde não há essas disposições, como nas Constituições supranacionais, exis- 
te sempre o perigo de os interesses dominantes se afirmarem hegemonicamente sob o véu de leis apartidariamente estabelecidas. Uma vinculação à legitimação interna aos Estados dos governos participantes pode preencher a necessidade de legitimação de sistemas de negociação transnacional, somente se as Constituições destes sistemas forem talhadas para a limitação e o equilíbrio do poder ${ }^{49}$.

Para Habermas, não se trata da questão empírica do quão forte é de fato a pressão por legitimação que uma esfera pública mundial exerce sobre a política da organização mundial e as decisões dos tribunais, mas antes, da questão teórica da formação global da opinião, em uma esfera pública informal, sem os meios institucionalizados pelo direito constitucional para converter a influência produzida comunicativamente em poder político, poder dar à sociedade cosmopolita uma integração e à organização mundial legitimidade suficientes ${ }^{50}$. Para a manutenção da paz e a proteção dos direitos humanos, a solidariedade dos cidadãos não precisa apoiar-se em valorações éticas fortes, mas em uma avaliação moral:

Basta um uníssono de indignação moral em relação a violações graves dos direitos humanos e infrações flagrantes da proibição de ações militares de agressão. Para a integração de uma sociedade de cidadãos do mundo bastam reações consensuais de sentimentos negativos em relação a atos de criminalidade em massa. Deveres univocamente negativos de uma moral universalista - o dever de suspensão das guerras de agressão e de crimes contra a humanidade - constituem, em última instância, o parâmetro para a função jurisdicional

\footnotetext{
49 HABERMAS, 2004, p. 140.

5o Ibid., p. 141. Segundo Brunkhorst, seria possível evitar que o direito hegemônico dos mais fortes se enclausure atrás da fachada de uma organização mundial a partir de uma esfera pública mundial, embora informal (esfera pública "fraca"), que abriria caminho para vincular, mesmo tenuamente, discussão e decisão. Sobre isso, ver: BRUNKHORST, Solidarität: Von der Bürgerfreundschaft zur globalen Rechtsgenossenschaft. Frankfurt: Suhrkamp, 2005.
} 
de tribunais internacionais e para as decisões políticas da organização mundial. Esta base para fazer um juízo, enraizada em disposições culturais comuns, é estreita, mas capaz. Por princípio, basta para agregar em todo mundo posições normativas que dizem respeito à agenda da comunidade de Estados e para conferir legitimidade às reações de uma esfera pública fortalecida pelas mídias e sempre pontualmente despertada..$^{51}$

Como o direito internacional já vem se desenvolvendo nessa direção:

Não é mera especulação a possibilidade conceitual de um sistema multidimensional, que em sua totalidade não adquire qualidade estatal, mas que, num plano supranacional, mesmo sem um governo mundial que monopolize a força, pode garantir os direitos humanos e, num plano transnacional, pode tratar dos problemas de uma política interna mundial. Não obstante, 0 estado de um mundo tomado por violência, é motivo suficiente para escarnecer dos sonhos de um visionário ${ }^{52}$.

\section{Proposta da democracia constitucional transnacional a partir do direito procedimental e da democracia deliberativa}

Em contrapartida à compreensão liberal como a de Kant, Habermas defende uma representação procedimental de uma constitucionalização do direito das gentes que, embora iniciada mais por governos do que por cidadãos, avançaria de forma gradativa para uma internacionalização das construções jurídicas ${ }^{53}$.

\footnotetext{
51 Ibid., p. 142.

52 Ibid., p. 143.

53 Habermas cita o exemplo da União Europeia e seus graus de institucionalização. Cf. HABERMAS, 2005, p. 325-331.
} 


\subsection{Motivos pelos quais Habermas retoma aspectos da teoria discursiva do direito, e sob os quais seria possível definir melhor o curso de uma conceptualização (juridificação) do direito internacional}

Na obra Im Sog der Technokratie, Habermas (2013) apresenta no capítulo 4 uma descrição pormenorizada da proposta de uma democracia transnacional a partir da compreensão procedimental da democracia e do direito ${ }^{54}$.

a) Primeiro motivo: o diagnóstico de quanto maior a complexidade da sociedade, menor a possibilidade de garantir a ideia de democracia na qual os endereçados do direito são ao mesmo tempo seus autores. Para Habermas, trata-se apenas de um modo político dos executivos, que apenas reagem aos imperativos sistêmico-funcionais e que desacopla a eleição dos políticos o tanto quanto possível dos processos de legitimação ${ }^{55}$. Em contrapartida, mesmo sob tais condições, seria plausível preservar uma abordagem comunicativa de uma promessa democrática de inclusão, da participação dos cidadãos no processo político. Não se pode restringir eleições e votos apenas ao ato de votar; ao contrário, eleições e votações apenas ganham peso institucional como colegisladores se vinculadas a uma livre dinâmica de opiniões, argumentos e afirmações "com" e "contra" em uma esfera pública. Escolhas políticas não podem ser apenas pesquisas de opinião, não devem ser apenas uma leitura de preferências momentâneas. Apesar dos avanços da revolução digital no sentido de uma rede comunicativa e mobilização da sociedade civil, devemos deixar de lado uma imagem institucional congelada dos Estados de direito demo-

\footnotetext{
54 Esta proposta foi apresentada de forma preliminar em um Seminário sobre Direito e democracia, em fevereiro de 2013, no Max-Planck Institut, Alemanha. Sobre isso, ver também: HABERMAS, Faktizität und Geltung: Beiträge zur Diskurstheorie des Rechts und des demokratischen Rechtsstaats. Frankfurt: Suhrkamp, 1992. Sobre democracia deliberativa e direito procedimental, ver: LUBENOW, esfera pública e democracia deliberativa em Habermas: modelo teórico e discursos críticos. Kriterion: Revista de Filosofia, n. 121, p. 227-258, 2010.
}

55 Cf. HABERMAS, Im Sog der Technokratie, 2013, cap. 4, p. 67. 
cráticos. A liquidificação comunicativa da política adequa-se como chave sociológica para o conteúdo realista do conceito de política deliberativa, e permite compreender a construção de um Estado constitucional como uma rede discursiva de formação da opinião e da vontade institucionalizada juridicamente ${ }^{56}$.

b) Segundo motivo: a abordagem da teoria discursiva resolve o paradoxo da legitimidade que resulta da legalidade. Em contrapartida, a teoria discursiva confere força legitimadora ao procedimento de formação democrática da opinião e da vontade ele mesmo legitimidade. Esse procedimento institucionalizado juridicamente fundamenta uma suposição falível sobre decisões racionais quando preencher ao menos duas condições: inclusão igual de todos os concernidos e seus representantes, e a reconexão das decisões democráticas na troca discursiva não coagida de cada tema e contribuição relevante. A fonte normativa da legitimidade surge com a combinação da inclusão de todos os atingidos e do caráter deliberativo da sua formação da opinião e da vontade. A ideia de uma formação livre racionalmente conduzida da vontade comum se manifesta assim na conexão entre inclusão e deliberação ${ }^{57}$.

c) Terceiro motivo: a reconciliação (Überbrückung) da oposição existente entre os princípios legitimadores da "soberania popular" e o "Estado de direito/primado da lei". Em contrapartida, a fundamentação da teoria discursiva do sistema de direitos pode conduzir para fora do impasse e considerar a intuição (der Intuition tragen) da co-originariedade de democracia e Estado de direito. O pressuposto, de que os sujeitos constituintes querer fundamentar uma livre associação de livre e igual usufruto (Rechtgenossen) dos direitos na linguagem do direito moderno de modo deliberativo, eles podem encontrar sua primeira decisão soberana apenas depois de terem se esclarecidos in abstracto,

56 Ibid., p. 67-68.

57 Ibid., p. 69. 
que tipo de liberdade de ação subjetiva eles precisam se conceder, antes de regular qualquer matéria com os meios do direito moderno. Sem essa intenção, faltaria ao legislador o medium (nesse caso, a linguagem) para legislar legitimamente ${ }^{58}$.

d) Quarto motivo: a arbitrariedade/conciliação (die Schlichtung) de uma insatisfatória disputa entre o paradigma do direito liberal e do Estado social. A estrutura conceitual básica dessa disputa relembra uma separação de papéis pela qual a compreensão deontológica do direito moderno se distingue da moral. O direito dos Estados modernos dividiu a pessoa moral até certo ponto em ambas pessoas cidadão da sociedade e cidadão do Estado. A integração entre ambos os papéis fornece a chave para avaliar os paradigmas do direito liberal e do Estado social. É assim que são nomeados os modelos de sociedade, nos quais opera o direito dos Estados democráticos de direito. Em contrapartida, Habermas aponta para um terceiro paradigma, o direito processual, discutido em Direito e Democracia, a atenção à autoautorização dos cidadãos que influenciam de modo coletivo suas sociais condições existenciais. No centro desse paradigma jurídico encontram-se laços reconectores (Rückkoppelungsschleifen) entre o processo democrático, que no interesse da sociedade civil gera direitos subjetivos e reivindicações, bem como a garantia da autonomia privada, que por sua vez possibilita um uso ativo da autonomia pública dos cidadãos. Uma reconexão positiva entre autonomia privada e pública é uma condição necessária para a legitimidade de um estado democrático de direito ${ }^{59}$.

58 Ibid., p. 70.

59 Ibid., p. 70-71. 


\subsection{Contribuições da abordagem discursiva para a problemática do direito das gentes (centrado nos Estados)}

As tendências de modificação na composição da forma dos meios do direito (a) e da dissolução da substância decisionista da dominação (b) vinculam-se com um déficit democrático (c), que apenas pode ser compensado com uma transnacionalização da democracia (d).

a) Com a globalização econômica, mudança na constelação pós-nacional. Os Estados nacionais perdem em termos de capacidade de controle. Esta lacuna é preenchida no nível da organização e cooperação internacional pelas Nações Unidas e outras organizações econômicas (Banco Mundial, FMI, OMC) ou informais (G8, G20). Isso implica um deslocamento na compreensão do direito internacional, e na constitucionalização do direito das gentes, como pode ser observado no caso da União Europeia. Do ponto de vista jurídico, significa uma mudança da composição da forma do direito (Rechtsmediums). Simultaneamente com o estado de agregação do domínio político altera-se também a constelação do direito e do poder político. Essa modificação espelha-se no peso relativo dos componentes, a partir dos quais se constitui o direito moderno. Se se parte da premissa que um monopólio da violência do Estado mundial ainda é possível e até desejável, então parece ser inevitável uma visão dualista do direito internacional e do direito constitucional do sistema jurídico global. Nesse nível, trata-se de um outro modo de validade e de um grau mais alto de eficácia do direito internacional, a quem falta o poder de sanção estatal como reserva de cobertura. $O$ direito internacional ampara a sua autoridade apenas em costumes, tratados internacionais, princípios jurídicos gerais conhecidos e no consenso entre os Estados. O problema seria que o reconhecimento da legitimidade de uma ordem jurídica sem o amparo do poder de sanção estatal não consegue garantir uma contínua obediência legal. No entanto, segundo Habermas (2013), essa configura- 
ção não encontra mais eco na realidade. Hoje, a validade do direito europeu é um exemplo do deslocamento do peso entre os componentes de coação do direito e o reconhecimento da sua legitimidade e observância do direito. Na União Europeia, o direito supranacional goza precedência sobre o direito nacional dos Estados-membros. No direito europeu, deslocou-se o peso relativo entre ambos os componentes do direito em favor de um reconhecimento da legitimidade da autoridade supraestatal (Conselho Europeu, Parlamento Europeu, Corte Europeia e Comissão Europeia). Também no âmbito do direito internacional é possível encontrar indícios de um deslocamento parecido entre os componentes de sanção e legitimação, desde a criação das Nações Unidas, e com o aumento de Cortes internacionais, a extensão do direito penal internacional e a propagação de organizações internacionais. Desse modo, "começa a se fechar a lacuna" entre a validade das sanções dos Estados e a validade fraca do direito internacional. Assim que se modificar o conceito rígido do direito moderno em um modo correspondente, parece também ser menos improvável o uso do monopólio do poder estatal para a implementação imparcial de decisões precipitadas e juridicamente controláveis em caso de reforma do Conselho de Segurança das Nações Unidas. ${ }^{60}$

b) Habermas conceitua a dissolução da decisionista substância violenta do exercício da dominação sob o ponto de vista da ciência política. Também no nível internacional é possível perceber sinais para uma racionalização do exercício do poder estatal, a qual corresponde uma alteração na composição dos meios do direito. No direito internacional clássico, o conceito de soberania estatal está vinculado a um conceito realista de poder estatal, e o poder político se manifesta na ação racional de autoafirmação de uma autonomia de ação dos Estados. Esses perseguem os seus interesses nacionais no palco da

$60 \quad$ Ibid., p. 74-75. 
concorrência entre os participantes, sem que o seu âmbito de ação seja limitado normativamente pelas considerações da comunidade de Estados. Trata-se de um modelo político de uma racional-instrumental afirmação e otimização de poder. No entanto, a densa rede de organizações internacionais desloca a imaginação do direito internacional clássico para uma outra base. Em uma sociedade mundial altamente dependente, até mesmo as potências pagam algum preço de autonomia funcional em diferentes campos políticos. Dado o número crescente de problemas, que apenas podem ser solucionados com uma ação política conjunta, todos os Estados se veem obrigados à cooperação. Isso elucida o aumento de organizações internacionais com competência regional ou até global e um correspondente alinhamento da política externa clássica às disputas com a política interna. O cerne decisionista do poder político se dissolve nos diluídos (Schmelztiegel) fluxos de comunicação de ações e discursos transnacionais. Os Estados não podem mais entender-se exclusivamente como sujeitos soberanos e que estabelecem contratos (vertragsschliessende), pois precisam agir também como membros da comunidade internacional ${ }^{61}$.

c) Da perspectiva da teoria discursiva descobre-se o crescente déficit democrático que se conecta com ambas as tendências citadas (a e b acima). As modificações na composição dos meios do direito e o exercício do poder político se esclarecem a partir da penetração de elementos deliberativos nas relações internacionais controladas pelo poder da sociedade mundial integrada sistemicamente ${ }^{62}$. No entanto, a juridificação de uma compactada cooperação entre Estados não consegue acompanhar a inclusão de cidadãos nos processos de decisão supranacionais (primeiro déficit). Pelo contrário, um governo

\footnotetext{
61 Ibid., p. 76-77.

62 Sobre as dificuldades da deliberação no âmbito mundial, ver as contribuições na Revista Acta Política: International Journal of Political Science, v. 40, n. 2 (jul.) e n. 3 (sep.), London, 2005, incluindo um texto de Habermas sobre o tema.
} 
efetivo para além do Estado nacional paga o preço de uma não compensada erosão dos processos de legitimação nacionais. A melhora do serviço das organizações, alcançada em um nível supranacional através da cooperação entre os Estados, pode ser compreendida como uma "racionalização" do exercício do poder. No entanto, apenas seria possível falar de uma "civilização" quando as organizações internacionais exercitarem as suas atribuições (Befugnisse) não apenas sobre a base de tratados internacionais, nas "formas" do direito, mas conforme o exercício legítimo do direito estabelecido de modo democrático. Além disso, (segundo déficit) em contraposição às decisões em gabinetes nacionais, que cobrem todos os âmbitos políticos, o trabalho funcional de organizações específicas está limitado à determinadas áreas de competência, de cuja estreita perspectiva os indesejados efeitos externos de decisões não podem ser reconectados. Por ambas as razões, na base jurídica dessa forma de trabalho organizado em conjunto está instalado um paternalismo, que não seria eliminado mesmo se as organizações internacionais fossem obrigadas a observar determinadas normas dos direitos humanos ${ }^{63}$. Esse déficit democrático apenas poderia ser compensado com uma transnacionalização da democracia.

d) Transnacionalização da democracia. O fato de impotentes sistemas de ação internacionais como as conferências do G8 ou G20 serem chamados à tona é entendido por Habermas como um sintoma de que a capacidade de controle das instituições existentes está sobrecarregada (überfordert) pelos desafios globais urgentes da mudança climática, da crise econômica mundial e pesos desiguais, dos riscos mundiais da técnica em larga escala, entre outros. As coerções sistêmicas que atravessam as fronteiras nacionais são forças sociais naturalizadas e que precisam ser domesticadas. A configuração de mais capa-

${ }_{63}$ Cf. HABERMAS, 2013, p. 77-78. 
cidades de ação supranacionais apenas agudizará o déficit de legitimidade. Sob a inocente etiqueta de "governança" apenas se propagarão ainda mais regimes tecnocráticos ${ }^{64}$, também para desenvolver uma legitimação democrática para as fontes de autoridade supranacional. Vencida é uma transnacionalização da democracia. Esse projeto afeta a relação entre política e mercado, e encontra do lado liberal econômico uma esperada resistência política. Nesse sentido, sugere Habermas, talvez a teoria do discurso possa contribuir na superação das barreiras concretas de pensamentos habituais (Denkgewohnheiten) ${ }^{65}$.

Um processo de legitimação democrático apenas se deixará expandir para além das fronteiras nacionais em uma comunidade política desnacionalizada quando os três elementos fundamentais (Bausteine), que são constitutivos para qualquer ordem democrática, puderem ser reunidos em um supranacional sistema multinível de modo diferente como no Estado nacional: apenas o Estado nacional traz consigo a cobertura dos âmbitos sociais, a saber, o cidadão (como portador da formação da vontade política), o Estado (como a organização que possibilita aos cidadãos um agir coletivo), e a constituição da sociedade civil (como a livre associação de livres e iguais). A ideia, de que cidadãos e Estados podem participar igualmente na constituição de uma democracia supranacional, incentiva a pensar sobre uma medida variável desses componentes. E aqui o conceito de soberania dividida não pode ser mal-entendido. Os Estados nacionais não devem participar como componentes "constituídos", mas como Estados membros de uma democracia supranacional "constituinte" do poder, e por esse motivo também manter as correspondentes competências dentro das comunidades constituídas ${ }^{66}$.

\footnotetext{
${ }^{64}$ Sobre o déficit democrático das instituições políticas da União Europeia, ver: LUBENOW, The paradox of technocratic democracy and the democratic deficit of european institutions by Jürgen Habermas. Aufklärung: Revista de Filosofia, v. 2, n. 2, p. 103-122, 2015.

65 Cf. HABERMAS, 2013, p. 78-79.

66 Ibid., p. 79-80.
} 
As implicações destas ideias podem ser observadas no exemplo da construção hipotética da união econômica para uma união política europeia. Dois exemplos podem ser úteis: i) Uma convenção no nível constitucional, que representa a unidade dos cidadãos dos Estados europeus participantes, e cada um em sua dupla atribuição, por um lado, como cidadão participante direto em uma futura união política e, por outro lado, como membro participante indireto de um povo europeu. Com base nessa composição da assembleia constituída por cidadãos europeus e pelo povo europeu, o processo de uma Constituição seria assim canalizado, que a força legitimadora da soberania popular dividida desde o início apenas poderia ser transferida para instituições de uma comunidade estatal supranacional. No processo de uma Constituição seria incorporado até um freio contra a Constituição de um Estado, como representantes do povo com a tarefa de delegar seus perspectivos cidadãos nacionais, assegurando a existência de futuros membros no seu papel de garantir um histórico já realizado nível de liberdade. Por isso, nenhuma das competências dos Estados-membros que são importantes para desempenhar essa função estariam à disposição no processo da Constituição. Esse arranjo teria previsíveis consequências internas não apenas para garantir a continuidade dos Estados-membros, para a sua hoje já existente condição de saída (Exit-Vorbehalt) assim como para a exigência de unanimidade para a alteração da Constituição. Consequências resultam sobretudo no sentido de uma distribuição de competências desviadas do modelo federativo. ii) Uma convenção que segue a sua tarefa no sentido de uma reforma dos Tratados existentes da União Europeia. Aqui seria reconhecível o desvio da futura união política do modelo de um Estado europeu já na retenção do direito de controle dos Tribunais Constitucionais nacionais. $O$ desvio atinge a necessária paridade distributiva dos cidadãos europeus e do povo europeu na formação do governo, para além da correspondente dupla responsabilidade para um governo da Comissão Europeia designada em oposição ao Parlamento europeu e Conselho, e sobretudo a contínua participação paritária de ambas as instituições na legislação. Também seria interessante manter a 
existente descentralização do monopólio do poder estatal bem como a implementação estatal da legislação, isso significa a renúncia a um nível de administração federal. Nesse sentido, a ideia da "soberania dividida" na raiz forneceria para uma tal divisão de competências entre instituições europeias e Estados-membros obviamente apenas o percurso, deixando uma margem significativa para a configuração (Ausgestaltung) concreta dos órgãos estatais e a divisão do poder no nível europeu. Diante disso, seria preciso discutir como poderiam ser juntados os elementos conhecidos das democracias parlamentar, presidencial e de concordância (Konkordanzdemokratien), que as circunstâncias europeias, sob o ponto de vista normativo, conseguem suportar uma comunidade supranacional simultaneamente democrática e capaz de ação ${ }^{67}$.

\section{Referências}

BRUNKHORST, Hauke. Legitimationskrisen: Verfassungsprobleme der Welgeselschaft. Baden-Baden: Nomos, 2012. https://doi. org/10.5771/9783845241524

BRUNKHORST, Hauke. (ed.). Demokratie in der Weltgeselschaft. BadenBaden: Nomos, 2009.

BRUNKHORST, Hauke. Solidarität: Von der Bürgerfreundschaft zur globalen Rechtsgenossenschaft. Frankfurt: Suhrkamp, 2005.

BRUNKHORST, Hauke. Globale Solidarität: Inklusionsprobleme moderner Gesellschaften. In: WINGERT, Lutz; GÜNTHER, Klaus (ed.). Die Öffentlichkeit der Vernunft und die Vernunft der Öffentlichkeit: Festschrift für Jürgen Habermas. Frankfurt: Suhrkamp, 2001. p. 605-626.

BRUNKHORST, Hauke; KÖHLER, Wolfgang; LUTZ-BACHMANN, Matthias (ed.). Recht auf Menschenrechte: Menschenrechte, Demokratie und internationale Politik. Frankfurt: Suhrkamp, 1999.

HABERMAS, Jürgen. Im Sog der Technokratie. Berlin: Suhrkamp, 2013. HABERMAS, Jürgen. Zur Verfassung Europas: Ein Essay. Berlin: Suhrkamp, 2011.

67 Ibid., p. 80-81. 
HABERMAS, Jürgen. Ach Europa: Kleinen Politischen Schriften. Frankfurt: Suhrkamp, 2008.

HABERMAS, Jürgen. Zwischen Naturalismus und Religion. Frankfurt: Suhrkamp, 2005 .

HABERMAS, Jürgen. Der gespaltene Westen. Frankfurt: Suhrkamp, 2004.

HABERMAS, Jürgen. Zeit der Übergänge. Frankfurt: Suhrkamp, 2001.

HABERMAS, Jürgen. Die postnationale Konstellation. Frankfurt: Suhrkamp, 1998.

HABERMAS, Jürgen. Die Einbeziehung des Anderen: Studien zur politischen Theorie. Frankfurt: Suhrkamp, 1996.

HABERMAS, Jürgen. Faktizität und Geltung: Beiträge zur Diskurstheorie des Rechts und des demokratischen Rechtsstaats. Frankfurt: Suhrkamp, 1992.

HEGEL, Georg Wilhelm Friedrich. Princípios da filosofia do direito. 2. ed. Trad. Norberto Lima. São Paulo: Ícone, 2005. p. 269.

KANT, Immanuel. A paz perpétua: um projeto filosófico. Trad. Artur Morão. Portugal: Universidade da Beira Interior, 2008.

KANT, Immanuel. Doutrina do direito. 2. ed. Trad. Edson Bini. São Paulo: Ícone, 1993.

LIMA, Francisco Jozivan Guedes de. A teoria kantiana das relações internacionais: pressupostos morais, jurídicos, políticos. Porto Alegre: Editora Fi, 2015.

LUBENOW, Jorge Adriano. Democracia e direitos humanos como ideologia: a crítica de Jürgen Habermas à política de poder unilateral norteamericana e à ONU. Aufklärung: Revista de Filosofia, João Pessoa, v. 5, n. 3, p. 141-154, 2018. https://doi.org/10.18012/arf.2016.43553

LUBENOW, Jorge Adriano. O Ocidente dividido: o impacto da globalização econômica neoliberal na integração política da União Europeia. Aufklärung: Revista de Filosofia, João Pessoa, v. 4, n. 3, p. 119-134, 2017. https://doi. org/10.18012/arf.2016.37553

LUBENOW, Jorge Adriano. A redefinição do perfil político da Europa de estatal-social para econômico-liberal: uma análise crítica a partir de Jürgen Habermas. Aufklärung: Revista de Filosofia, João Pessoa, v. 3, n. 2, p. 95-112, 2016. https://doi.org/10.18012/arf.2016.30972

LUBENOW, Jorge Adriano. The paradox of technocratic democracy and the democratic deficit of european institutions by Jürgen Habermas. Aufklärung: 
Revista de Filosofia, João Pessoa, v.2, n.2, p. 103-122, 2015. https://doi. org/10.18012/arf.2015.25907

LUBENOW, Jorge Adriano. A categoria de esfera pública em Jürgen Habermas. 2. ed. Curitiba: CRV, 2015.

LUBENOW, Jorge Adriano. Hauke Brunkhorst e o conceito de solidariedade democrática como crítica à esfera pública pós-nacional de Jürgen Habermas. Veritas: Revista de Filosofia, v.58, n.1, p. 118-130, 2013. https://doi. org/10.15448/1984-6746.2013.1.13568

LUBENOW, Jorge Adriano; SILVA, Bartolomeu Leite da. Esfera pública 50 anos depois. Dossiê Revista Problemata, João Pessoa, v. 3, n. 2, p. 228-274, 2012.

LUBENOW, Jorge Adriano; SILVA, Bartolomeu Leite da; AZEVEDO, Edmilson Alves de. Habermas 80 anos. Rio de Janeiro: Tempo Brasileiro, 2010. $2 \mathrm{v}$.

LUBENOW, Jorge Adriano. Esfera pública e democracia deliberativa: modelo teórico e discursos críticos. Kriterion: Revista de Filosofia, Belo Horizonte, $\mathrm{n}$. 121, p. 227-258, 2010. https://doi.org/10.1590/S0100-512X2010000100012 NOUR, Soraya. À paz perpétua: filosofia do direito internacional e das relações internacionais. São Paulo: Martins Fontes, 2004.

\section{Endereço Postal}

E-mail: jlubenow@hotmail.com

Universidade Federal da Paraíba. Centro de Ciências Humanas, Letras e Artes. Programa de Pós-graduação em Filosofia. Cidade Universitária - João Pessoa/PB 